\title{
Comparing the accuracy of estimating soil moisture using the Standardized Precipitation Index (SPI) and the Standardized Precipitation Evapotranspiration Index (SPEI)
}

\author{
Dwi Priyo Ariyanto ${ }^{1 *}$, Abdul Aziz ${ }^{2}$, Komariah ${ }^{1}$, Sumani ${ }^{1}$, Magarsa Abara ${ }^{3}$ \\ ${ }^{1}$ Department of Soil Science, Faculty of Agriculture, Sebelas Maret University, Surakarta, Central Java, Indonesia \\ ${ }^{2}$ Undergraduate Program of Soil Science, Faculty of Agriculture, Sebelas Maret University, Surakarta, Central Java, Indonesia \\ ${ }^{3}$ Department of Environmental Science, Wollega University, Oromia, Ethiopia
}

\begin{tabular}{|c|c|}
\hline ARTICLE INFO & ABSTRACT \\
\hline Keywords: & The Standardized Precipitation Index (SPI) and the Standardized Precipitation \\
\hline Drought & \multirow{9}{*}{ 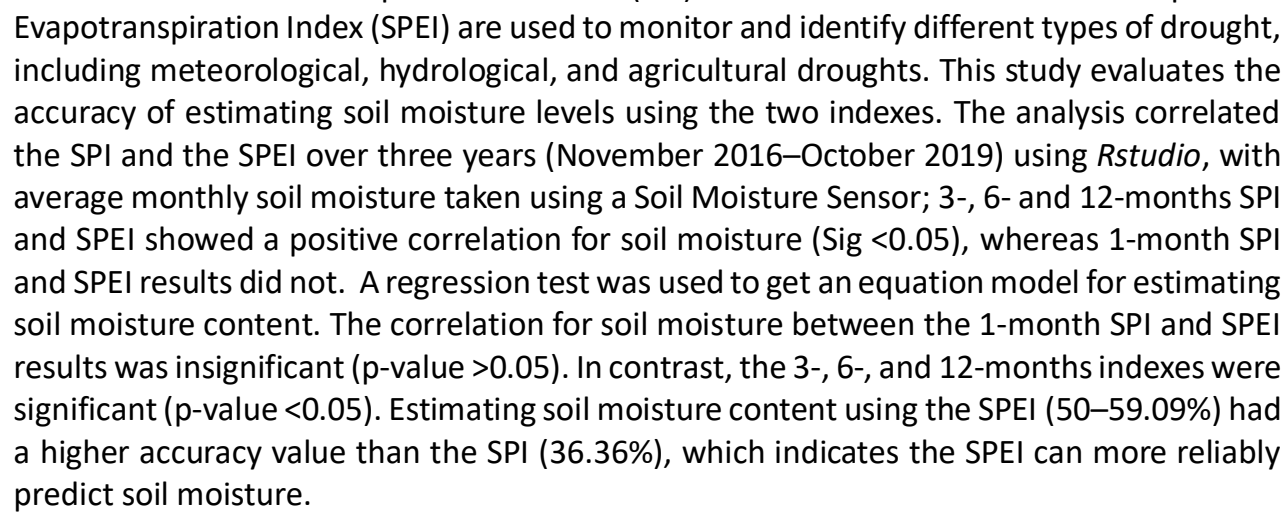 } \\
\hline Drought index & \\
\hline Soil moisture content & \\
\hline Irrigation management & \\
\hline Article history & \\
\hline Submitted: $2020-04-29$ & \\
\hline Accepted: $2020-06-26$ & \\
\hline * Corresponding Author & \\
\hline $\begin{array}{l}\text { Email address: } \\
\text { dp_ariyanto@staff.uns.ac.id }\end{array}$ & \\
\hline
\end{tabular}

How to Cite: Ariyanto, D.P., Aziz, A., Komariah, Sumani, and Abara, M. (2020). Comparing the accuracy of estimating soil moisture using the Standardized Precipitation Index (SPI) and the Standardized Precipitation Evapotranspiration Index (SPEI). Sains Tanah Journal of Soil Science and Agroclimatology, 17(1): 23-29 (doi: 10.20961/stjssa.v17i1.41396)

\section{Introduction}

Drought describes the hydrological conditions of an area with an uneven distribution of rain, rain being an area's only water input (Jamil, Tjahjono, \& Parman, 2013). Agricultural drought is drought caused by low water availability, which causes stunted plant growth-the availability of water in the soil is the most significant abiotic factor influencing plant growth and production (Djazuli, 2010). Drought is a response to soil moisture, which, at a certain level, can be dangerous for plants and the environment (Taufik \& Setiawan, 2012). Soil moisture is the water content in the soil; when it is reduced, the soil cannot provide water for plants (Muliawan, Harisuseno, \& Suhartanto, 2015). Greater degrees of drought can cause a reduced supply of water for plants, inhibiting plant growth, and reducing production (Saputra, Timotiwu, \& Ermawati, 2015).

Various indexes have been developed to detect and monitor drought and have been used to analyze meteorological drought for different regions. The drought index is used to assess the effects of drought and to determine various drought characteristics, such as duration, intensity, and severity (Mishra \& Singh, 2010). The most commonly used meteorological drought index is the Standardized Precipitation Index (SPI), which has the principal advantage of calculation on different time scales. McKee, Doesken, and Kleist (1993) proposed the SPI concept based on long-term precipitation over a particular period; it is suitable for drought analysis on various scales of time and can be used to monitor both agricultural drought and hydrological drought. The benefit of using SPI to monitor hydrological drought has been proven by Andika, Harisuseno, and Suhartanto (2016), who suitably compared the results of drought analyses with the SPI method to the magnitude of discharge in the Bagong River.

Vicente-Serrano, Bagueria, and Lopez-Moreno (2010) proposed a new drought index called the Standardized Precipitation Evapotranspiration Index (SPEI). This index is based on anomalies in the water balance and deficits of precipitation and potential evapotranspiration. The SPEI can 
identify an increase in the severity of drought events where water demand increases due to evapotranspiration. Additionally, the SPEI index can be calculated on different time scales, assessing drought susceptibility and describing the characteristics of drought events, including severity, duration, time intervals, intensity, probability, and return period. Furthermore, the SPI index cannot identify the impact of temperature rise on drought conditions and is independent of global warming effects; thus, it cannot explain the effect of temperature variability. In contrast, SPEI can identify increases in the severity of drought events caused by evapotranspiration-led increased water demand and can explain the possible effects of temperature variability and extreme temperatures.

The SPI can monitor river discharge, making the task easier and more practical by eliminating the need to go into the field and wait, meaning data obtained can be kept accurate and up to date (Andika et al., 2016). The World Meteorological Organization (2012) explains that the SPI index can be used to monitor agricultural drought conditions, especially soil moisture. But until now, studies using the SPI and the SPEI to estimate soil moisture content have been limited; thus, this study analyzes the SPI and SPEI drought index to estimate soil moisture and determine the accuracy of estimating moisture using the SPI and the SPEI.

\section{Materials and Method}

\subsection{Data source and collection}

The soil moisture data were obtained from the Experimental Field Jumantono, Karanganyar Regency, Indonesia ( $7^{\circ} 37^{\prime} 49.814^{\prime \prime} \mathrm{S}$ and $110^{\circ} 56^{\prime}$ 52.408“E). According to Nurcahyani, Sumarno, and Sudadi (2014), the type of soil in the Experimental Field Jumantono is Alfisol, which features a clay texture and a very stable aggregate. According to Ariyanto, Komariah, Sumani, and Setiawan (2019), land in Jumantono feature $46.04 \%$ moisture content, and the permanent wilting point is $27.53 \%$. The bulk density of soil in Jumantono is 1.12 gram cm$~^{-3}$; this value is normal for claytexture soil types. Karanganyar Regency has a tropical climate with temperatures between 18 and $31^{\circ} \mathrm{C}$ and average annual precipitation of 7,231.4 mm (BPDB Karanganyar, 2019). Soil moisture was determined automatically using the Soil Moisture Sensor at a sensor depth of $20 \mathrm{~cm}$; data were recorded every 10 minutes for three years (November 2016October 2019). The soil-moisture-content data were downloaded as an Excel file using the DataTrac application every month during the observation period. Sensor data were recorded in the form of resistance data $\left(\mathrm{m}^{3} / \mathrm{m}^{3}\right)$, which must be calibrated with actual soil moisture. The soil moisture was rendered as a percentage of total volume. Out of 36 months of soil moisture data, 22 months were used as a sample for correlation and regression analyses (Figure 3). The SPI used precipitation data, while the SPEI used precipitation and maximum- and minimum-temperature data. The climate data used covered the previous 30 years (September 1989October 2019). However, maximum- and minimumtemperature data were missing from the data collection for the SPI and the SPEI. Therefore, the missing data were estimated using a simple linear regression prediction method (Fadholi, 2013).

\subsection{Data analysis}

The SPI and SPEI analyses were conducted by Rstudio with the SPEI package. Precipitation and maximum- and minimumtemperature data were calculated through Rstudio to complete the SPI and the SPEI. The SPI can be calculated for many timescales, meaning it can process many different drought types due to its temporal flexibility in the evaluation of precipitation conditions concerning the water supply. The SPI was designed to quantify the precipitation deficit for multiple timescales by moving averaging windows. These timescales reflect the impacts of drought on different water resources. In the context of agricultural drought, meteorological and soil moisture conditions respond to precipitation anomalies on relatively short timescales (1-6 months), whereas streamflow, reservoirs, and groundwater respond to longer-term precipitation anomalies (6-24 months and longer). The SPI and SPEI for this research were calculated at 1-, 3-, 6-, and 12-months; the data used for analysis was index data for the previous three years (November 2016-October 2019). The SPI and SPEI values can be used to categorize the severity of the drought based on Table 1's SPI and SPEI classifications.

Table 1. SPI and SPEI index classifications (McKee et al., 1993)

\begin{tabular}{cc}
\hline SPI and SPEI & Category \\
$\geq 2.0$ & extremely wet \\
$1.5-1.99$ & very wet \\
$1.0-1.49$ & moderately wet \\
$-0.99-0.99$ & near normal \\
$-1.0--1.49$ & moderately dry \\
$-1.5--1.99$ & severely dry \\
$\leq-2.0$ & extremely dry \\
\hline
\end{tabular}

A descriptive correlative was conducted to understand the relationship between soil moisture according to both the SPI and the SPEI. Correlation analyses for soil moisture, as measured by each index, were conducted using 22 observational samples.

A regression analysis was also conducted where parameter significantly correlated; that is, if the parameters were correlated positively or negatively, they passed to the regression phase. The regression test was used to determine the causal relationship between soil moisture for the SPI and the SPEI; an equation model estimating soil moisture levels was used for this purpose.

\section{Results}

\subsection{SPI and SPEI}

Figures 1 and 2 show SPI and SPEI data derived from observations between November 2016 and October 2019. The negative SPI and SPEI values indicate a precipitation deficit, meaning drought has been detected. Meanwhile, a positive index value indicates excess precipitation or suggests that the period is classified as the wet period. Table 1 categorizes wetness and drought levels. 


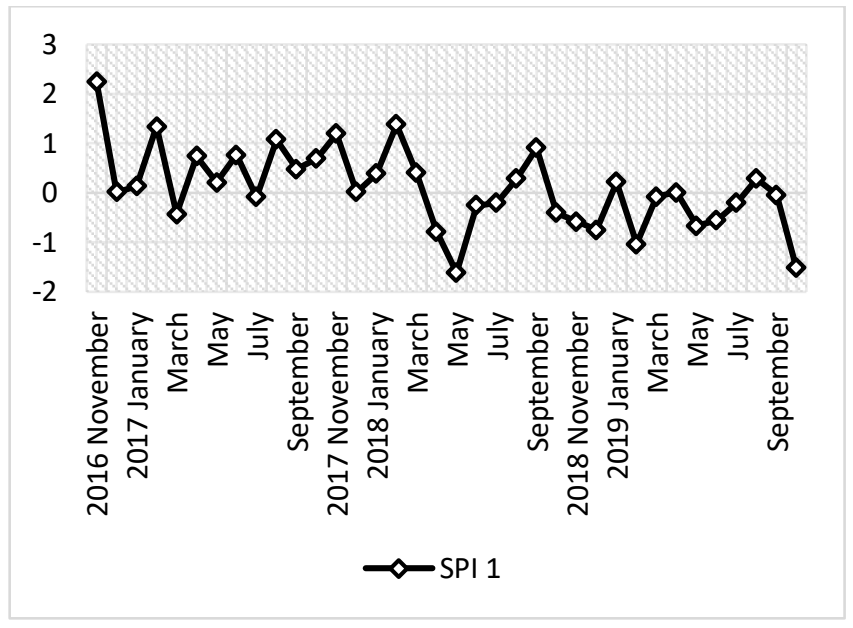

(a)

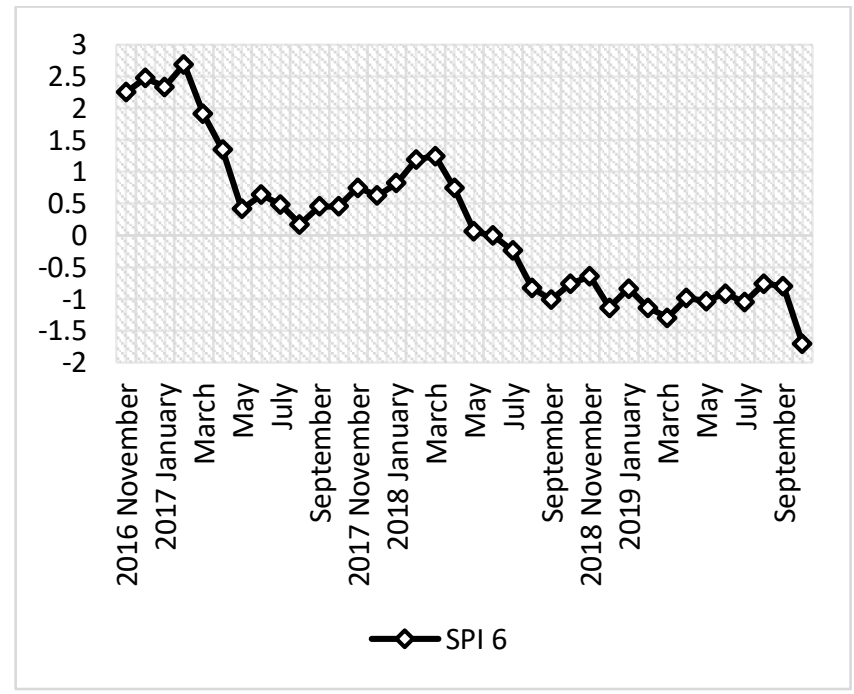

(c)

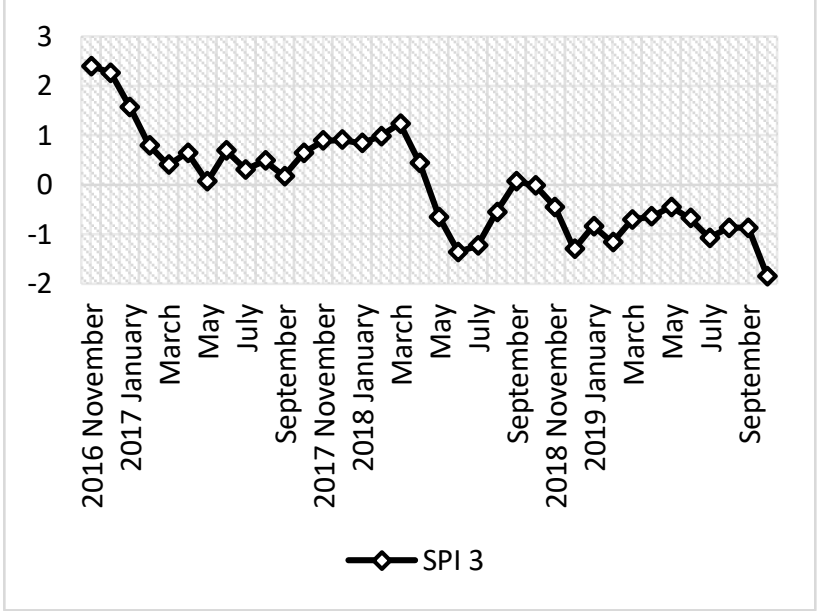

(b)



(d)

Figure 1. Graph of SPI: (a) 1-month SPEI; (b) 3-months SPEI; (c) 6-months SPEI; (d) 12-months SPEI

Figures 1a and 2a show 1-month SPI and SPEI values fluctuate substantially; this is not the case for 3-, 6-, and 12months values. This is because the 1-month indexes analyze the monthly deviation of meteorological conditions. Therefore, the slightest deviation in a certain month greatly affects the index value. The SPI user guide explains that the 1month SPI may be misinterpreted unless climatology elements are understood thoroughly. Precipitation irregularities will cause the SPI value to be largely negative or positive, even if the deviation is relatively small.

The SPI and SPEI charts for 3-months (Figures $1 \mathrm{~b}$ and $2 \mathrm{~b}$ ), 6-months (Figures $1 \mathrm{c}$ and $2 \mathrm{c}$ ), and 12-months (Figures $1 \mathrm{~d}$ and 2d) show descending trends between March 2018 and October 2019. The negative index supply indicates a bulk rain deficit, which can cause drought. The 3-months SPI values (Figure 1b) indicate the lowest index value was for October 2018, with a value of -1.849 classifying it as dry; the highest index value was for November 2016, with a value of 2.403 classifying it as very wet. Meanwhile, the 3-months SPEI values (Figure $2 \mathrm{~b}$ ) indicate the lowest index value was for
December 2018 , with a value of -1.293 classifying it as rather dry; the highest index value was for December 2016, with a value of 2.105 classifying it as very wet.

The 6-months SPI values (Figure 1c) indicate the lowest index value was for October 2019, with a value of -1.709 classifying it as dry; the highest index value was for February 2017, with a value of 2.692 classifying it as very wet. Meanwhile, the 6-months SPEI index value (Figure 2c) indicates the lowest index value was for March 2019, with a value of -1.236 classifying it as rather dry; the highest index value was for February 2016, with a value of 2.196 classifying it as very wet. The 12-months SPI values (Figure 1d) indicate the lowest index value was for September 2019, with a value of -1.475 classifying it as rather dry; the highest index value was for January 2017, with a value of 2.282 classifying it as very wet. Meanwhile, the 12-months SPEI index values (Figure 2d) indicate the lowest index value was for March 2019 , with a value of -1.463 classifying it as rather dry; the highest index value was for June 2017, with a value of 2.217 classifying it as very wet. 


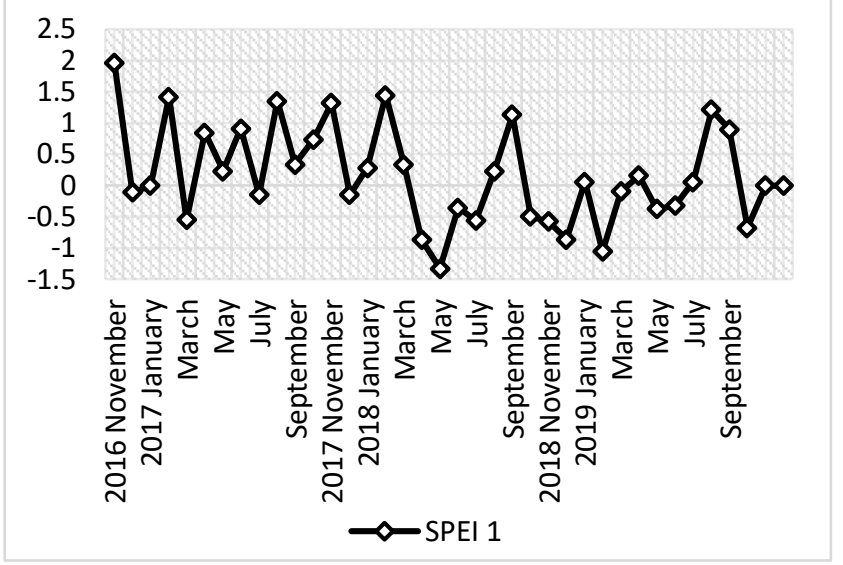

(a)
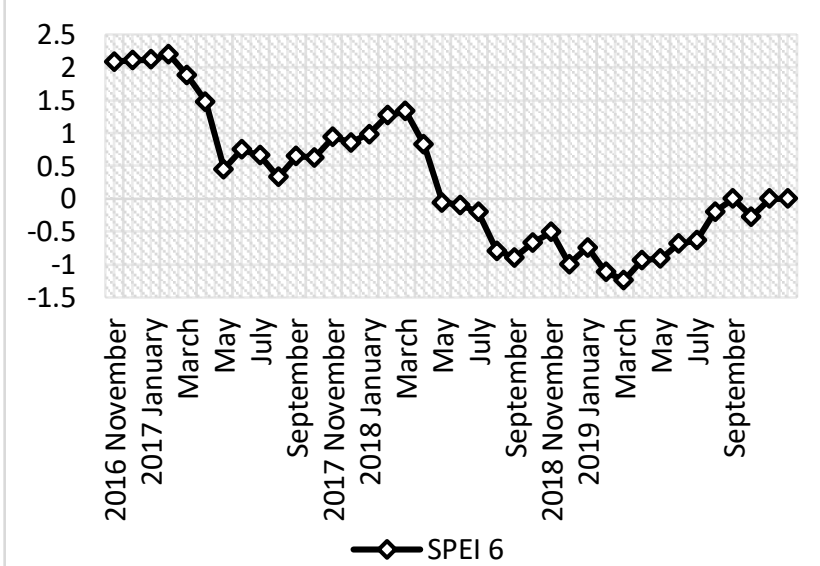

(c)

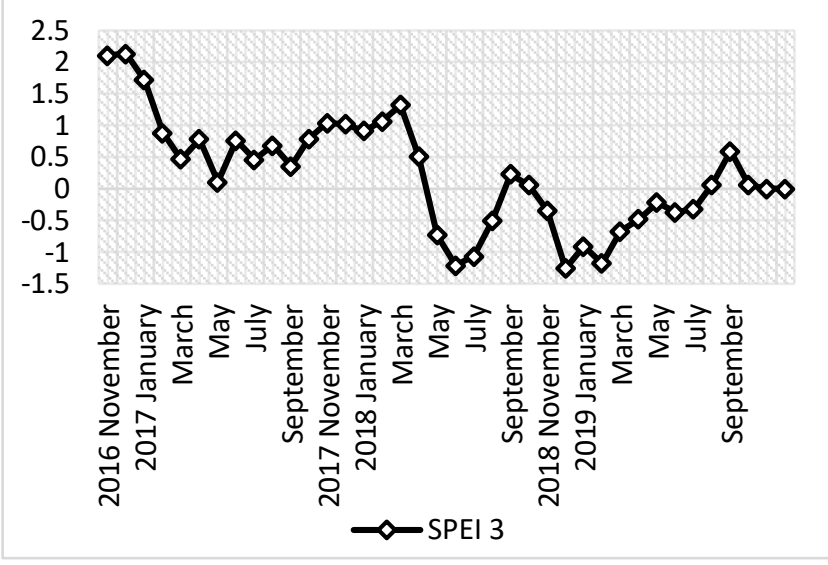

(b)

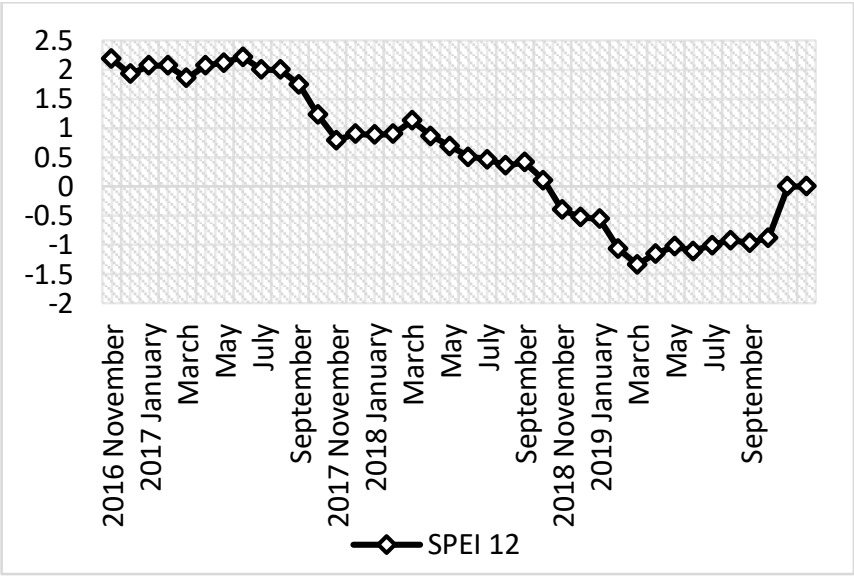

(d)

Figure 2. Graph of SPEI index: (a) 1-month SPEI; (b) 3-months SPEI; (c) 6-months SPEI; (d) 12-months SPEI

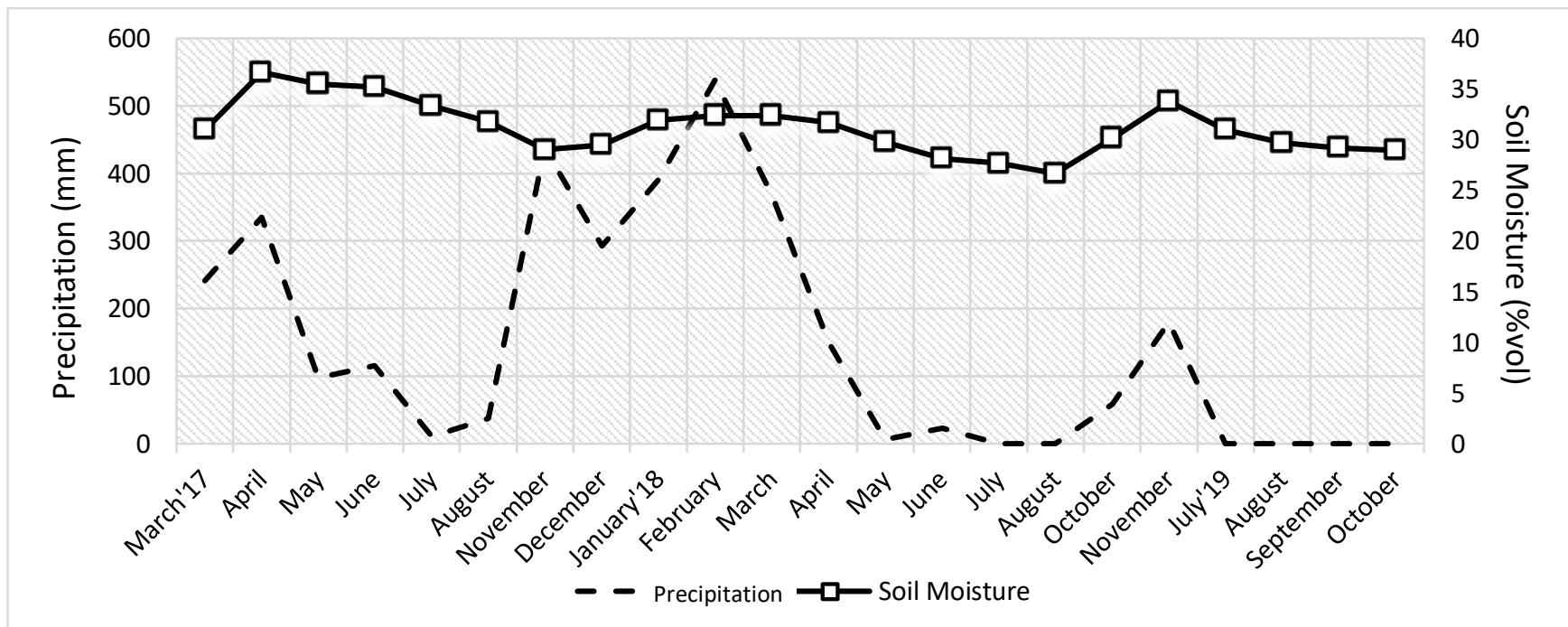

Figure 3. Soil moisture and precipitation

\subsection{Soil moisture}

Out of 36 months of observation, 22 months of soil moisture data were selected based on the completeness of the data and the suitability of the monthly rain intensity; Figure 3 shows soil-moisture-sample data, indicating fluctuations each month due to precipitation intensity. The biggest supply of groundwater comes from rainwater, so the dynamics of precipitation can also affect the dynamics of soil moisture. The highest soil moisture level was recorded in April 2016 (36.64\%), while the lowest soil moisture level was recorded in August 2018 (26.66\%). 


\subsection{Correlation between the SPI and SPEI soil moisture}

\section{levels}

Tables 2 and 3 shows Pearson's correlation between soil moisture according to the SPI and the SPEI; the 3-, 6-, and 12month SPIs and SPEIs are correlated (Sig $<0.05)$. This proves the existence of a significant relationship; the 1-month indexes show no correlation for soil moisture levels (Sig $>0.05)$. The relationship between the 3-, 6-, and 12-months SPIs and SPEIs for soil moisture is positively correlated; that is, directly proportional.

Table 2. Pearson's correlation for soil moisture and SPI

\begin{tabular}{ccc}
\hline SPI Index & $\mathbf{r}$ & Sig \\
\hline SPI 1 & 0.293 & 0.186 \\
SPI 3 & 0.519 & $0.013^{*}$ \\
SPI 6 & 0.477 & $0.025^{*}$ \\
SPI 12 & 0.594 & $0.004^{*}$ \\
\hline
\end{tabular}

Remark: Grey cell indicates no significant correlation $(\alpha=0.05)$

Table 3. Pearson's correlation for soil moisture and SPEI

\begin{tabular}{ccc}
\hline SPEI Index & $\mathbf{r}$ & Sig \\
\hline SPEI 1 & 0.227 & 0.310 \\
SPEI 3 & 0.445 & $0.038^{*}$ \\
SPEI 6 & 0.481 & $0.023^{*}$ \\
SPEI 12 & 0.577 & $0.005^{*}$ \\
\hline
\end{tabular}

Remark: Grey cell indicates no significant correlation ( $\alpha=0.05)$

\subsection{Soil moisture modeling using the SPI and the SPEI}

Table 4 shows the regression analysis for soil moisture according to the 3-, 6-, and 12-months SPIs and SPEIs. The three periods were chosen because of their significant relationship. The regression analysis for soil moisture content produced varied coefficient determination values. The highest coefficient determination value for soil moisture modeling using the two indexes was for the 12-months period.

\subsection{Estimating soil moisture using SPI and SPEI index}

Table 5 displays estimates of soil moisture according to the SPIs and SPEls for the three different periods. The estimation table enables easy estimation of soil moisture content using the SPI and SPEI estimation intervals.
Table 4. Soil moisture modeling using SPI and SPEI index

\begin{tabular}{ccc}
\hline \multicolumn{1}{c}{ Period } & Model & $\mathbf{R}^{\mathbf{2}}$ \\
\hline \multicolumn{1}{l}{ SPI } & & \\
3-months & $\mathrm{y}=1.5249(\mathrm{x})+31.217$ & 0.2694 \\
6-months & $\mathrm{y}=1.3544(\mathrm{x})+30.922$ & 0.2271 \\
12-months & $\mathrm{y}=1.276(\mathrm{x})+30.417$ & 0.3529 \\
\hline SPEI & & \\
3-months & $\mathrm{y}=1.6371(\mathrm{x})+30.720$ & 0.1981 \\
6-months & $\mathrm{y}=1.6427(\mathrm{x})+30.524$ & 0.2317 \\
12-months & $\mathrm{y}=1.4199(\mathrm{x})+30.137$ & 0.3330 \\
\hline
\end{tabular}

\subsection{Accuracy of soil moisture modeling using the SPI and the SPEI}

Table 6 shows the different accuracy values between the SPI and the SPEI. The accuracy value of estimating soil moisture content using the SPI was smaller by $36.36 \%$ for all three periods; 3- and 12-months SPEI accuracy was smaller by $50 \%$, while the 6 -months SPEI was $59.09 \%$ smaller.

\section{Discussion}

Estimating soil moisture content using the SPI and the SPEI was not highly accurate. Nonetheless, Table 6 shows the SPI accuracy value was $36.36 \%$ smaller for all three periods, compared to the SPEI values, which were smaller by $50 \%$ for the 3-and 12 -months periods and $59.09 \%$ for the 6 -months period. This is consistent with a study conducted by VicenteSerrano et al. (2012), which found that the accuracy of the SPEI for monitoring ecological, agricultural, and hydrological conditions is $10 \%$ higher than the accuracy of the SPI; that is, the SPEI modeling's accuracy value is higher than that of the SPI index. This is because the SPEI index calculation model performs an evapotranspiration calculation, resulting in knowledge of how much water has been lost or evaporated on the ground.

Meanwhile, the SPI calculation does not consider the effect of evapotranspiration, a statement supported by $\mathrm{Li}, \mathrm{Li}$, Yuan, Zhang, and Sha (2018), who stated that the SPEI more sensitively monitors soil moisture characteristics than the SPI. This is because the SPEI considers precipitation and evapotranspiration in its calculation model. According to Fuchs (2012), SPEI is an evolution of the SPI and can more capably identify drought indications in climate change trends. Therefore, estimating soil moisture content is more reliable with the SPEI than with the SPI.

Table 5. Estimating soil moisture using the SPI and the SPEI

\begin{tabular}{ccccccc}
\hline \multirow{2}{*}{ SPI and SPEI } & \multicolumn{2}{c}{ Soil moisture using SPI (\% vol) } & \multicolumn{2}{c}{ Soil moisture using SPEI (\% vol) } \\
\cline { 2 - 7 } & 3-months & 6-months & 12-months & 3-months & 6-months & 12-months \\
\hline$\geq 2.0$ & $\geq 34.27$ & $\geq 33.63$ & $\geq 32.97$ & $\geq 33.99$ & $\geq 33.81$ & $\geq 32.98$ \\
$1.5-1.99$ & $33.50-34.25$ & $32.95-33.62$ & $32.33-32.96$ & $33.18-33.98$ & $32.99-33.79$ & $32.27-32.96$ \\
$1.0-1.49$ & $32.74-33.49$ & $32.28-32.94$ & $31.69-32.32$ & $32.36-33.16$ & $32.17-32.97$ & $31.56-32.25$ \\
$-0.99-0.99$ & $29.71-32.73$ & $29.58-32.26$ & $29.15-31.68$ & $29.10-32.34$ & $28.90-32.15$ & $28.73-31.54$ \\
$-1.0--1.49$ & $29.69-28.94$ & $29.57-28.90$ & $29.14-28.52$ & $29.08-28.28$ & $28.88-28.08$ & $28.72-28.02$ \\
$-1.5--1.99$ & $28.93-28.18$ & $28.89-28.23$ & $28.50-27.88$ & $28.26-27.46$ & $28.06-27.26$ & $28.01-27.31$ \\
$\leq-2.0$ & $\leq 28.17$ & $\leq 28.21$ & $\leq 27.87$ & $\leq 27.45$ & $\leq 27.24$ & $\leq 27.30$ \\
\hline
\end{tabular}


Table 6. Accuracy of soil moisture modeling using SPI and SPEI index

\begin{tabular}{ccccccc}
\hline \multirow{2}{*}{ Method } & \multicolumn{2}{c}{ Soil moisture using SPI } & \multicolumn{3}{c}{ Soil moisture using SPEI } \\
\cline { 2 - 7 } & 3-months & 6-months & 12-months & 3-months & 6-months & 12-months \\
\hline Accuracy (\%) & 36.36 & 36.36 & 36.36 & 50.00 & 59.09 & 50.00 \\
\hline
\end{tabular}

The recommended SPI and SPEI regression formulation for monitoring soil moisture conditions (Table 4) was for the 3months period because there was a significant relationship ( $p$-value $<0.05$ ) in the correlation analysis (Tables 2 and 3). Additionally, the coefficient of determination, or the accuracy level, is high and does not differ considerably from other periods; furthermore, seasonal cropping patterns in Indonesia comprise 3-month periods. This is supported by Spennemann, Rivera, Saulo, and Penalba (2015), who used a 3-months dryness index to monitor and evaluate agricultural production.

Soil moisture levels for the SPI and the SPEI are positively correlated, or directly proportional, with various $p$-values. Correlation for the 1-month SPI and SPEI showed no significant relationship ( $p$-value $>0.05$ ), while the $3-, 6-$, and 12 -months indexes show significant relationships ( $p$-value $<0.05$ ) (see Tables 2 and 3). This accords with the SPI user guide, published by the World Meteorological Organization (2012), which stated that the 3-months SPI is positively correlated with soil moisture, a statement supported by Kubicz (2018), who showed that the SPI has a relationship with hydrological drought and soil moisture conditions.

The regression analyses for soil moisture content for the SPI and SPEI for each period have almost the same determination coefficient (Table 4). This is consistent with research by Rogers and Munroe (in Wang, Rogers, \& Munroe, 2015), which stated that SPEI and SPI work in the same way and have a high potential for monitoring soil moisture conditions in the area. Wang's et al., (2015) research, meanwhile, showed that SPI and SPEI values have a relationship with soil moisture conditions in various layers of soil $(0-100 \mathrm{~cm})$.

The regression analyses for soil moisture content for the SPI and the SPEI demonstrated various determination coefficients (Table 4). The determination coefficient, or the accuracy level, of SPI and SPEI modeling of estimated soil moisture, is not substantial because it is influenced by other factors. This is supported by (Wang et al., 2015), who stated that the relationship between drought indexes and soil moisture is influenced by soil properties, including the precipitation density of the soil and the organic-carbon density of the soil. The soil texture in Jumantono is clay, which makes infiltration slow and can affect soil moisture, as suggested by Morgan ( 1995), who recognized that soils with coarse textures, such as sand or sandy loam, demonstrate greater infiltration than clay because they feature larger soil pore spaces.

\section{Conclusion}

The accuracy value for soil moisture estimates using the SPEI was $50-59.09 \%$, compared to the SPI's $36.36 \%$. Soil moisture can be estimated using the SPI and SPEI periods of 3-, 6-, and 12-months.

\section{Declaration of Competing Interest}

The authors declare no competing financial or personal interests that may appear and influence the work reported in this paper.

\section{References}

Andika, I. A., Harisuseno, D., \& Suhartanto, E. (2016). Penerapan metode standardized precipitation index (SPI) untuk analisa kekeringan di DAS Ngasinan Kabupaten Trenggalek. Retrieved from http://pengairan.ub.ac.id/s1/wpcontent/uploads/2016/01/Penerapan-MetodeStandardized-Precipitation-Index-SPI-untuk-AnalisaKekeringan-di-DAS-Ngasinan-KabupatenTrenggalek_Indi-Anin-Andika_125060400111001.pdf

Ariyanto, D. P., Komariah, Sumani, \& Setiawan, I. (2019). Actual evapotranspiration model based on the irrigation volume of the maize fields on Alfisols. SAINS TANAH - Journal of Soil Science and Agroclimatology, 16(1), 24-35. https://doi.org/10.20961/stjssa.v16i1.25218

BPDB Karanganyar. (2019). Sekilas pandang Kabupaten Karanganyar. Retrieved February 5, 2020, from http://bpbd.karanganyarkab.go.id/?p=28\#: :text=Men gingat letak geografi dan topografi,mencapai suhu $310 \mathrm{C}$

Djazuli, M. (2010). Pengaruh cekaman kekeringan terhadap pertumbuhan dan beberapa karakter morfo-fisiologis tanaman nilam. Buletin Littro, 21(1), 8-17.

Fadholi, A. (2013). Persamaan regresi prediksi curah hujan bulanan menggunakan data suhu dan kelembapan udara di Ternate. Statistik, 13(1), 7-16.

Fuchs, B. (2012). Using the standardized precipitation index (SPI) and the standardized precipitation evapotranspiration index (SPEI). Retrieved February 8, 2020, from https://drought.unl.edu/archive/Documents/NDMC/ Workshops/136/Pres/Brian Fuchs--SPI and SPEI.pdf

Jamil, D. H., Tjahjono, H., \& Parman, S. (2013). Deteksi potensi kekeringan berbasis penginderaan jauh dan sistem informasi geografis di Kabupaten Klaten. Geo Image, 2(2), 30-37. https://doi.org/10.15294/geoimage.v2i2.2195

Kubicz, J. (2018). TLM method and SGI Index as an indicator of groundwater drought. Acta Scentiarum Polonorum Formatio Circumiectus, 17(1), 115-123. https://doi.org/10.15576/ASP.FC/2018.17.1.115

Li, Y., Li, Y., Yuan, X., Zhang, L., \& Sha, S. (2018). Evaluation of model-based soil moisture drought monitoring over three key region in China. Journal of Applied Meteorology and Climatology, 57, 1989-2003. https://doi.org/10.1175/JAMC-D-17-0118.1 
McKee, T. B., Doesken, N. J., \& Kleist, J. (1993). The relationship of drought frequency and duration to time scales. In Eighth Conference on Applied Climatology (pp. 179-184). Anaheim, California: American Meteorological Society.

Mishra, A. K., \& Singh, V. P. (2010). A review of drought concepts. Journal of Hydrology, 391(1-2), 202-216. https://doi.org/10.1016/j.jhydrol.2010.07.012

Morgan, R. P. C. (1995). Soil erosion and conservation (Second Edi). London, UK: Longman Publishing Group.

Muliawan, H., Harisuseno, D., \& Suhartanto, E. (2015). Analisa indeks kekeringan dengan metode standardized precipitation index (SPI) dan sebaran kekeringan dengan geographic information system (GIS) pada DAS Ngrowo. Retrieved February 12, 2020, from http://pengairan.ub.ac.id/wpcontent/uploads/2014/02/Analisa-Indeks-Kekeringandengan-Metode-Standardized Precipitation-Index-SPIdan-Sebaran-Kekeringan-dengan-

GeographicInformation-System-GIS-pada-DAS-

Ngrowo-Hadi-Muliawan-0910640007.pdf

Nurcahyani, V., Sumarno, \& Sudadi. (2014). The effect of Azolla inoculum, phosphate rock, and rice hull ash dosages on rice yield and soil physical of Alfisols. SAINS TANAH - Journal of Soil Science and Agroclimatology, 11(1), 61-68. https://doi.org/10.15608\%2Fstjssa.v11i1.219

Saputra, D., Timotiwu, P. B., \& Ermawati. (2015). Pengaruh cekaman kekeringan terhadap pertumbuhan dan produksi benih lima varietas kedelai. Jurnal Agrotek
Tropika, 3(1). https://doi.org/10.23960/jat.v3i1.1881

Spennemann, P. C., Rivera, J. A., Saulo, A. C., \& Penalba, O. C. (2015). A comparison of GLDAS soil moisture anomalies against standardized precipitation index and multisatellite estimations over South America. Journal of Hydrometeorology, 16(1), 158-171. https://doi.org/10.1175/JHM-D-13-0190.1

Taufik, M., \& Setiawan, B. I. (2012). Interpretation of soil water content into dryness index: implication for forest fire management. Jurnal Manajemen Hutan Tropika, 18(1), 31-38. https://doi.org/10.7226/jtfm.18.1.31

Vicente-Serrano, S. M., Bagueria, S., \& Lopez-Moreno, J. I. (2010). A multiscalar drought index sensitive to global warming: The standardized precipitation evapotranspiration index. Journal of Climate, 23(7), 1696-1718. https://doi.org/10.1175/2009JCLI2909.1

Vicente-Serrano, S. M., Bagueria, S., Lorenzo-Lacruz, J., Camarero, J. J., Lopez-Moreno, J. I., Azorin-Molina, C., ... Sanchez-Lorenzo, A. (2012). Performance of drought indices for ecological, agricultural, and hydrological applications. Earth Interactions, 16(10), 1-27. https://doi.org/10.1175/2012EI000434.1

Wang, H., Rogers, J. C., \& Munroe, D. K. (2015). Commonly used drought indices as indicators of soil moisture in China. Journal of Hydrometeorology, 16(3), 1397-1408. https://doi.org/10.1175/JHM-D-14-0076.1

World Meteorological Organization. (2012). Standardized precipitation index user guide. Geneva, Switzerland: World Meteorological Organization. 